Journal of Energy and
Environmental Sustainability
Journal homepage : www.jees.in

\title{
Catalytic Hydrothermal Liquefaction of Castor Residue: Effect on Product Yield and Distribution of Liquid Product
}

\author{
Ravneet Kaur ${ }^{1,2}$, Poonam Gera ${ }^{1}$, Mithilesh Kumar Jha ${ }^{1}$, Thallada Bhaskar, ${ }^{2} 3^{*}$ \\ ${ }^{1}$ Dr B R Ambedkar National Institute of Technology, Jalandhar 144011, India, \\ ${ }^{2}$ Biomass Conversion Area (BCA), Materials Resource Efficiency Division (MRED), CSIR-Indian Institute of Petroleum (IIP), Dehradun 248005, India, \\ ${ }^{3}$ Academy of Scientific and Innovative Research (AcSIR), New Delhi
}

\section{A R T I C L E I N F O}

Received : 20 June 2019

Revised : 28 August 2019

Accepted : 04 October 2019

Keywords:

Castor residue,

Hydrothermal liquefaction,

Alkali catalysts,

Bio-oil

\author{
A B S T R A C T
}

Castor plant (Ricinus communis) is an evergreen perennial shrub, typically found in India, Eastern Africa, and tropical regions.Hydrothermal liquefaction (HTL) of castor plant residue (leaves and stem) was performed at different operating temperatures $\left(260,280,300^{\circ} \mathrm{C}\right)$ at a residence time of $60 \mathrm{~min}$ in the presence of alkali catalysts ( $\mathrm{KOH}, \mathrm{K}_{2} \mathrm{CO}_{3}$ ). The maximum total bio-oil yield (TBO) of ca. 21.2 wt.\% was obtained at $300^{\circ} \mathrm{C}, 60 \mathrm{~min}$ and in the presence of $0.5 \mathrm{M} \mathrm{K}_{2} \mathrm{CO}_{3}$. The obtained bio-products (bio-oil, bio-char) have been analyzed using the Elemental analysis (CHNS), Gas Chromatography-Mass Spectrometry (GC-MS),Fourier transform infrared spectroscopy (FT-IR), Proton Nuclear magnetic resonance spectroscopy ( ${ }^{1} \mathrm{H}$ NMR), X-ray diffraction (XRD), and Scanning electron microscopy (SEM).The major compounds identified in bio-oil by GC-MS were phenols, aromatic hydrocarbons, $\mathrm{N}$-contained compounds, aldehydes, ketones, amides, alcohols, and acids.

\section{Introduction}

In 2018, fossil fuels such as natural gas, oil, and coal contributed 24.0, 34.0 , and $27.2 \%$ respectively in the World's primary energy consumption (BP Statistical Review of World Energy, 2019). The increase in fossil fuels demand, changes in climate, and decreases in crude-oil reserves have shifted the global dependence on fossil-based energy resources to renewable energy production technologies. The drawbacks of firstgeneration biofuels associated with its availability and competition with the food vs. fuel are replaced by second-generation biofuels. Lignocellulosic biomass, a second-generation feedstock is abundant in nature, and carbonneutral renewable energy resource can be used for the production of biofuels, bio-chemicals and value-added products. Woody biomass, agricultural residues and by-products, organic wastes, energy grown plantations, variety of grass are the different sources of biomass (Kaur et al., 2019a).

The different conversion routes of biomass to biofuels are biochemical and thermochemical. The biochemical pathway includes the enzymatic transformation of hemicellulose and cellulose to sugars and subsequent fermentation to bioethanol. Thermochemical process(es) involves the heating of biomass in the presence/absence of air or oxygen and categorized are as Combustion, Gasification, Pyrolysis, and Liquefaction (Kaur et al., 2015). Hydrothermal liquefaction (HTL) conversion process includes the conversion of biomass in subcritical water to hydrocarbons (Peterson et al., 2008), and the obtained liquid product is referred as biocrude or bio-oil. HTL gained more attention as compared to other thermal conversion technologies due to its advantages. One of significant advantages of hydrothermal liquefaction is that it prevents the need for drying of the feedstocks for producing biocrude (Xiu and Shahbazi, 2012).

Castor plant (Ricinus communis) is an evergreen plant from Euphorbiaceae family and genus Ricinus. It is mainly grown in India, Eastern Africa, tropical and subtropical regions. Castor plant is widely found along stream banks, distributed areas, river beds, bottomlands by self-pollination. The plant is divided into three parts: seeds, stem, and leaves. Globally, the maximum production of castor seed is in India and India ranks first with production of $22,36,000$ MT seeds in 2016 (Comprehensive Castor Oil Report, 2017). The oil obtained from seeds has many industrial and medicinal applications. The other parts of the plant (stem and leaves) contribute more than $50 \%$ of residue generation based on per ton of castor plant (Bateni and Karimi, 2016). The research on each part of the castor plant was performed as castor oil is used for biodiesel production by different researchers (Berman et al., 2011; Canoira et al., 2010; Panwar et al., 2010; Pradhan et al., 2012) and they conclude that reduction of castor oil viscosity from $226.82 \mathrm{cS}$ to $8.50 \mathrm{cS}$

*Corresponding Author: : tbhaskar@iip.res.in 
at $38^{\circ} \mathrm{C}$ is required to make it available a transportation fuel. The various parameters that affect the yield of fatty acid methyl esters are catalyst concentration and methanol to oil molar ratio. A positive interaction was observed among the effect of catalyst concentration, methanol to oil molar ratio and reaction temperature. The kinetic study on castor bean presscake was reported by different researchers (Santos et al., 2015; Thiagarajan, 2016). The study reported on pyrolysis of castor bean cake concludes that the highest bio-oil yield of $63 \%$ was obtained at reaction temperature of $400^{\circ} \mathrm{C}$ for $60 \mathrm{~min}$ (Aldobouni et al., 2015). The kinetic study on castor residue (leaves and stems) was reported first time to understand the pyrolytic characteristics, kinetics and thermodynamic properties of feedstock (Kaur et al., 2018). This study concludes that the obtained kinetic and thermodynamic results can be useful input for the design of pyrolytic process. Overall, it was found that the castor residue has significant energy so that it can be used as a feedstock for bioenergy applications. Hydrothermal liquefaction of castor residue at different reaction temperature $\left(260,280,300^{\circ} \mathrm{C}\right)$ and residence time of $15-90 \mathrm{~min}$ in the presence of water was performed. Reaction temperature is the main parameter that affects the total bio-oil (TBO) yield and the optimum residence time based on maximum TBO yield (15.8 wt.\%) was $60 \mathrm{~min}$ (Kaur et al., 2019b). Based on the above conclusions, the optimum residence time of $60 \mathrm{~min}$ was used in the present study to understand the effect of temperature and catalyst on product yield.

To best of our knowledge, no study has been reported yet on catalytic hydrothermal liquefaction of castor residue (leaves and stems) in open literature. With the same aim, hydrothermal liquefaction of castor residue was carried out at $260,280,300^{\circ} \mathrm{C}$ at residence time of $60 \mathrm{mins}$ in the presence of alkali catalyst $\left(\mathrm{KOH}\right.$ and $\left.\mathrm{K}_{2} \mathrm{CO}_{3}\right)$. Alkali based homogenous catalysts $\left(0.5 \mathrm{M} \mathrm{KOH}, 0.5 \mathrm{M} \mathrm{K}_{2} \mathrm{CO}_{3}\right)$ were used to know the effect of catalyst on product yield and formation of compounds. The obtained bio-products were analyzed by Elemental analysis (CHNS), Gas Chromatography-Mass Spectrometry (GC-MS), Fourier transform infrared spectroscopy (FT-IR), Proton Nuclear magnetic resonance spectroscopy ( ${ }^{1} \mathrm{H}$ NMR), X-ray diffraction (XRD), and Scanning electron microscopy (SEM).

\section{Material and Methods}

\subsection{Raw material}

The castor residue used in this work was collected from the boundary of Dr B R Ambedkar National Institute of Technology $\left(31.3962^{\circ} \mathrm{N}\right.$, $\left.75.5354^{\circ} \mathrm{E}\right)$, Jalandhar, Punjab. After crushing and sieve shaking, the obtained fine powder was used for further analysis. The catalyst $(0.5 \mathrm{M}$ $\mathrm{KOH}, 0.5 \mathrm{M} \mathrm{K}_{2} \mathrm{CO}_{3}$ ) was prepared in lab. Proximate analysis, elemental analysis, and component analysis of castor residue was performed, and the methods used were explained in our previous study (Kaur et al., 2018). HHV of castor residue and bioproducts were calculated using Dulong's formula:

Heating value $(\mathrm{MJ} / \mathrm{kg})=0.338 \mathrm{C}+1.428(\mathrm{H}-\mathrm{O} / 8)+0.095 \mathrm{~S}$

\subsection{Apparatus and experimental procedure}

Hydrothermal liquefaction experiments were conducted in a highpressure batch autoclave (Parr reactor) at different reaction conditions in the presence of alkaline catalysts $\left(\mathrm{KOH}, \mathrm{K}_{2} \mathrm{CO}_{3}\right)$. In each catalytic hydrothermal experiment, the reactor was loaded with castor residue and alkaline solutions with a ratio of 1:6 (by weight). Then the reactor was sealed and purged with nitrogen for atleast 5 times to remove the inside air. The reactants were then agitated vertically with $\approx 200 \mathrm{rpm}$ using vertical magnetic stirrer. The reactor was then heated upto desired temperature $\left(260,280,300^{\circ} \mathrm{C}\right)$ for residence time of $60 \mathrm{~min}$. The reactor was then left to cool down to the room temperature.

\subsection{Extraction of liquid products and analysis}

After cooling of the reactor, gaseous products were vented out.The liquid and solid products were then separated using vacuum filtration. Diethyl ether of equal quantity was then added to liquid portion for its recovery. Phase separation of liquid product in organic and aqueous fraction was carried out in a separating funnel. The obtained organic or ethereal fraction was then dried over anhydrous sodium sulfate to remove the moisture or water content. Diethyl ether was then extracted using rotary vacuum evaporator under reduced pressure. The obtained fraction was then designated as bio-oil 1 or BO1. The aqueous phase is a mixture of water-soluble oxygenated hydrocarbons, designated as others and watersoluble oxygenated hydrocarbons (WSH). The acetone soluble fraction was then extracted out from solid product in soxhlet apparatus using acetone as solvent until the solvent in thimble become colorless. The liquid fraction obtained after evaporating the acetone under reduced pressure was weighed and termed as bio-oil 2 or $\mathrm{BO} 2$. The insoluble acetone fraction was then dried at $105^{\circ} \mathrm{C}$ and designated as bio-char or $\mathrm{BC}$. The mass balance equations used in this procedure are:

$$
\begin{aligned}
& \text { Conversion, } \%=\frac{W_{\text {feed }}-W_{\text {bio-char }}}{W_{\text {feed }}} \times 100 \\
& \text { Bio }- \text { oil } 1 \text { or BO1 yield }=\frac{W_{\text {ether-soluble }}}{W_{\text {feed }}} \times 100 \\
& \text { Bio - oil } 2 \text { or BO2 yield, wt. } \%=\frac{W_{\text {acetone-soluble }}}{W_{\text {feed }}} \times 100 \\
& \text { Bio }- \text { char or BC yield }, w t . \%=\frac{W_{\text {bio-char }}}{W_{\text {feed }}} \times 100 \\
& \text { Gas yield, wt. } \%=\frac{R 1-R 2}{R 3} \times 100 \\
& \text { Other yield, wt. } \%=100-(\text { bio }- \text { oil } 1+\text { bio }- \text { oil } 2+\text { bio }- \text { char }+ \text { gas })
\end{aligned}
$$

$W_{\text {feed }}:$ is the weight of feed; $W_{\text {bio-char }}$ is the weight of bio-char; $W$ is the weight of ether soluble bio-oil or BO1; $W_{\text {acctonesoluble }}$ : is the weight of acetone soluble bio-oil or BO2. R1 = Initial weight of the reactor + feed + solvent before HTL; R2 = Final weight of the reactor + feed + solvent after HTL. R3 = Amount of feed taken (g) + Amount of solvent added (g).

Castor residue was analyzed using FT-IR, XRD, and SEM. The liquid fraction is the most desirable product in the hydrothermal liquefaction, and the optimum conditions are where maximum amount of total bio-oil was attained. Further, the bio-products (bio-oil and bio-char) obtained at the particular optimum conditions were analyzed using FT-IR, GC-MS, ${ }^{1} \mathrm{HNMR}$, Elemental analysis, SEM, and XRD.

\section{Results and discussions}

\subsection{Feedstock analysis}

Castor residue has carbon, hydrogen, nitrogen, and oxygen content of 43.59 wt. $\%, 5.56$ wt. $\%, 4.69$ wt. $\%, 46.16$ wt.\% respectively. Moisture, ash, fixed carbon and volatile matter content present in castor residue was 11.14 wt. $\%, 5.40 \mathrm{wt} . \%, 9.16 \mathrm{wt} . \%$, and $74.30 \mathrm{wt} . \%$ respectively.The high heating value of castor residue calculated using Dulong's formula was $14.43 \mathrm{MJ} / \mathrm{kg}$. Castor residue is lignocellulosic biomass and has cellulose, hemicellulose and lignin content of $38.42 \mathrm{wt} . \%, 22.40 \mathrm{wt} . \%$ and $20.20 \mathrm{wt} . \%$ respectively. Extractives in the form of gum, resins, and proteins, etc are also part of castor residue and observed as $16.40 \mathrm{wt} . \%$.

\subsection{HTL products yields}

Table 1 depicts the product distribution of castor residue obtained after catalytic hydrothermal liquefaction. Equations (2) to (7) were used to calculate the yield of the product. Temperature and catalysts affect the total bio-oil yield and conversion. The trend of conversion for $\mathrm{K}_{2} \mathrm{CO}_{3}$ was first decreases at $280^{\circ} \mathrm{C}$ and then increases with further increase in temperature $\left(300^{\circ} \mathrm{C}\right)$ was observed and highest conversion of $85.0 \mathrm{wt} . \%$ was found at $300^{\circ} \mathrm{C}$ in the presence of $\mathrm{K}_{2} \mathrm{CO}_{3}$. The conversion for $\mathrm{KOH}$ varies from $68.6,77.6,82.8 \mathrm{wt} . \%$ for 260,280 , and $300^{\circ} \mathrm{C}$ respectively. It was observed that the maximum total bio-oil yield of ca. $21.2 \mathrm{wt} . \%$ was observed at $300^{\circ} \mathrm{C}$ in the presence of $\mathrm{K}_{2} \mathrm{CO}_{3}$. The maximum total bio-oil yield of ca. 12.2 wt. $\%$ was obtained at $300^{\circ} \mathrm{C}$ when $\mathrm{KOH}$ is used as catalyst. It was observed that the TBO yield was more in $\mathrm{K}_{2} \mathrm{CO}_{3}$ means it is more effective catalyst as compared to $\mathrm{KOH}$. Similar to this, HTL of wheat husk was conducted in the presence of both alkali catalysts $(\mathrm{KOH}$ and $\mathrm{K}_{2} \mathrm{CO}_{3}$ ) at $280^{\circ} \mathrm{C}$ for $15 \mathrm{~min}$, and similar conclusion was made that the $\mathrm{K}_{2} \mathrm{CO}_{3}$ is more reactive then $\mathrm{KOH}$ (Singh et al., 2013). The maximum total bio-oil yield of 30 and 31 wt.\% was obtained in the presence of $\mathrm{KOH}$ and $\mathrm{K}_{2} \mathrm{CO}_{3}$ respectively. The other studies (Bhaskar et al., 2008; Karagoz et al., 2005; Singh et al., 2015) reported in literature proved the same reactivity of alkali catalysis. The possible reason for the behavior of alkali salts during sub-critical process is they react and form their bases and bicarbonates. Bicarbonates may act as secondary catalyst and enhance the product yield (Karagoz et al., 2005). The effect of alkali catalysts on total bio-oil yield was observed by comparing the values with our 
previously reported study (Kaur et al., 2019b) where water was used as catalyst, and it was concluded the $0.5 \mathrm{M} \mathrm{K}_{2} \mathrm{CO}_{3}$ was the most reactive catalyst. The major fraction of others or WSH fraction was observed ranging from 50.7-65.7 and 49.7-56.7 wt.\% for $\mathrm{KOH}$ and $\mathrm{K}_{2} \mathrm{CO}_{3}$ respectively and possibly derived from carbohydrates present in castor residue. The biochar yield varies between 17.2-31.4 wt.\% and 15.0-30.8 wt.\% for $\mathrm{KOH}$ and $\mathrm{K}_{2} \mathrm{CO}_{3}$ respectively. An increase in the TBO yield with increase in temperature was due to the decomposition of solids and condensation of gases (Liu and Zhang, 2008).

Table 1: Product distributions, wt.\% of castor residue from catalytic hydrothermal liquefaction at different reaction conditions.

\begin{tabular}{l|c|c|c|c|c|c|c}
\hline \multirow{2}{*}{$\begin{array}{c}\text { Sample } \\
\text { Code }\end{array}$} & \multicolumn{2}{|c|}{ Bio-oils } & Total & & Bio-oil \\
\cline { 2 - 6 } & $\begin{array}{c}\text { Bio-oil } \\
2\end{array}$ & Bio-oil & Gases & $\begin{array}{c}\text { Bio- } \\
\text { char }\end{array}$ & $\begin{array}{c}\text { Other } \\
\text { yield }\end{array}$ & $\begin{array}{c}\text { Con- } \\
\text { vers- } \\
\text { ion }\end{array}$ \\
\hline $\begin{array}{l}260-60 \\
0.5 \mathrm{M} \mathrm{KOH}\end{array}$ & 7.2 & 2.4 & 9.6 & 8.3 & 31.4 & 50.7 & 68.6 \\
\hline $\begin{array}{l}280-60 \\
0.5 \mathrm{M} \mathrm{KOH}\end{array}$ & 8.8 & 1.2 & 10 & 5.9 & 22.4 & 61.7 & 77.6 \\
\hline $\begin{array}{l}300-60 \\
0.5 \mathrm{M} \mathrm{KOH}\end{array}$ & 8.6 & 3.6 & 12.2 & 4.9 & 17.2 & 65.7 & 82.8 \\
\hline $\begin{array}{l}260-60 \\
0.5 \mathrm{M} \mathrm{K} \mathrm{CO}_{3}\end{array}$ & 15.2 & 0.2 & 15.4 & 7.5 & 27.4 & 49.7 & 72.6 \\
\hline $\begin{array}{l}280-60 \\
0.5 \mathrm{M} \mathrm{K}_{2} \mathrm{CO}_{3}\end{array}$ & 13.8 & 0.2 & 14 & 10.0 & 30.8 & 45.2 & 69.2 \\
\hline $300-60$ & 20.8 & 0.4 & 21.2 & 7.1 & 15.0 & 56.7 & 85.0 \\
\hline $0.5 \mathrm{M} \mathrm{K}_{2} \mathrm{CO}_{3}$ & 20.2 &
\end{tabular}

\subsection{Feedstock and Product characterization}

\subsubsection{GC-MS analysis of BO1}

Table 2 represents the compounds obtained in $\mathrm{BO} 1$ of castor residue from catalytic hydrothermal liquefaction at $300^{\circ} \mathrm{C}$ for 60 mins in the presence of $0.5 \mathrm{M} \mathrm{KOH}$ and $\mathrm{K}_{2} \mathrm{CO}_{3}$. NIST mass spectral database was used for the identification of compounds. The chemical compounds of bio-oil were identified as phenolics, aromatic hydrocarbons, N-contained compounds, aldehydes, ketones, amides, alcohols, and acids. It was observed that the use of catalyst affects the formation of compounds. A maximum area \% 28.22 of compound 5-Bromo-4-oxo-4,5,6,7tetrahydrobenzofurazan was observed when $\mathrm{KOH}$ was used as catalyst. Compounds such as Stigmasterol, $\gamma$-Sitosterol, Isophytol, Phytol, Eicosane, $\gamma$-Tocopherol, Butylated Hydroxytoluene, 2-Pentadecanone, 6,10,14trimethyl- was observed in both catalysts but the area \% of the similar compounds was quite high in case of $\mathrm{KOH}$ as compared to $\mathrm{K}_{2} \mathrm{CO}_{3}$. The formation of compounds 2-Cyclopenten-1-one, Phenol, p-Cresol, Benzene, 3-Methoxybenzyl alcohol, Indole was observed when HTL of castor residue was done in the presence of $\mathrm{K}_{2} \mathrm{CO}_{3}$. It was observed that the area $\%$ of phenolic compounds were more and can be used as a feedstock in chemical and pharmaceutical industry or as a substitute for bio-phenolic resins etc.

\subsubsection{FT-IR analysis ofcastor residue and BO1}

Figure 1 shows the FT-IR analysis of castor residue and $\mathrm{BO} 1$ obtained after catalytic $\mathrm{HTL}$ of castor residue at $300^{\circ} \mathrm{C}$. The absorption peak ranges between $3200-3600 \mathrm{~cm}^{-1}$ is due to $\mathrm{N}-\mathrm{H}$ and $\mathrm{O}-\mathrm{H}$ stretching represents the presence of amides/amines, alcohols and phenols. The C$\mathrm{H}$ stretching vibrations at $2800-3000 \mathrm{~cm}^{-1}$ indicates the presence of alkanes (Aysu, 2014). The $\mathrm{C}=\mathrm{O}$ stretching vibrations between 1680-1800 $\mathrm{cm}^{-1}$ indicate the presence of ketones, carboxylic acids, and aldehydes. Besides, the $C=C$ stretching peak between $1400-1600 \mathrm{~cm}^{-1}$ suggests the presence of aromatics, and the substituted aromatic groups are observed at $675-900 \mathrm{~cm}^{-1}$ (Guo et al., 2008). The C-H deformation vibrations between $1360-1460 \mathrm{~cm}^{-1}$ show the presence of alkane group. The vibrations in the region $1020-1300 \mathrm{~cm}^{-1}$ were assigned to C-N stretching vibrations which are possibly due to aliphatic amines. The significant difference between the vibrations of castor residue and $\mathrm{BO} 1$ is the absence of peak in the range of $1680-1800 \mathrm{~cm}^{-1}$ in castor residue, while the remaining vibrations were similar in all samples. Comparing the FT-IR analysis obtained under different catalytic conditions $\left(\mathrm{KOH}\right.$ and $\mathrm{K}_{2} \mathrm{CO}_{3}$ ), it was noticed that the almost same functional groups were present in both $\mathrm{BO} 1$ but at different relative intensity.
Table 2: Major compounds identified in $\mathrm{BO} 1$, Area, \%of castor residue from catalytic hydrothermal liquefaction using GC-MS.

\begin{tabular}{|c|c|c|c|}
\hline $\mathrm{RT}$ & Library/ID & $\begin{array}{l}\mathrm{BO} 1300-60 \\
0.5 \mathrm{M} \mathrm{KOH}\end{array}$ & $\begin{array}{ll}\mathrm{BO} 1 & 300-60 \\
0.5 \mathrm{M} & \mathrm{K}_{2} \mathrm{CO}_{3}\end{array}$ \\
\hline 3.63 & Cyclopentanone, 2-methyl- & - & 3.42 \\
\hline 4.36 & 1-Butylpyrrolidine & - & 1.36 \\
\hline 4.77 & Cyclopentanone, 2-ethyl- & - & 1.03 \\
\hline 5.64 & Phenol & - & 8.71 \\
\hline 6.27 & Pyridine-D5- & - & 0.74 \\
\hline 6.28 & N-.beta.-Hydroxyethylpyrrolidine & 1.71 & - \\
\hline 6.32 & Pyridine, 5-ethyl-2-methyl- & - & 0.70 \\
\hline 6.42 & 2-Cyclopenten-1-one, 2,3-dimethyl- & - & 3.02 \\
\hline 6.79 & $\begin{array}{l}\text { 1-Butanamine, } \\
\text { 2-methyl-N-(2-methylbutylidene)- }\end{array}$ & - & 0.61 \\
\hline 7.14 & p-Cresol & - & 1.80 \\
\hline 7.51 & $\begin{array}{l}\text { 2-Cyclopenten-1-one, } \\
\text { 3,4,4-trimethyl- }\end{array}$ & - & 7.22 \\
\hline 7.59 & Phenol, 2-methoxy- & - & 2.61 \\
\hline 8.02 & $\begin{array}{l}\text { 2-Cyclopenten-1-one, } \\
\text { 2,3,4,5-tetramethyl- }\end{array}$ & - & 1.18 \\
\hline 8.85 & 1,3-Benzenediamine, 4-methoxy- & - & 0.65 \\
\hline 8.99 & Creosol & - & 0.60 \\
\hline 9.22 & Benzene, 1-methoxy-4-methyl- & - & 1.46 \\
\hline 9.50 & 3-Methoxybenzyl alcohol & - & 0.48 \\
\hline 9.77 & Phenol, 3-ethyl- & - & 0.52 \\
\hline 9.88 & 2-Ethyl-3,5-dimethylpyridine & - & 0.80 \\
\hline 11.47 & Quinoline, 1,2,3,4-tetrahydro- & - & 0.63 \\
\hline 12.36 & Indole & - & 2.36 \\
\hline 14.49 & 1H-Indole, 4-methyl- & - & 1.52 \\
\hline 17.77 & Butylated Hydroxytoluene & 8.39 & 7.00 \\
\hline 24.92 & $\begin{array}{l}\text { 2-Pentadecanone, } 6,10, \\
\text { 14-trimethyl- }\end{array}$ & 1.99 & 0.81 \\
\hline 26.99 & Isophytol & 4.39 & 1.48 \\
\hline 29.85 & Phytol & 4.61 & 4.50 \\
\hline 41.72 & Eicosane & 3.33 & 1.40 \\
\hline 43.06 & $\gamma$-Tocopherol & 2.29 & 1.67 \\
\hline 44.04 & Vitamin E & 5.17 & 2.00 \\
\hline 45.57 & Stigmasterol & 6.00 & 2.23 \\
\hline 46.43 & $\gamma$-Sitosterol & 16.29 & 5.40 \\
\hline 46.55 & 2-Ethylacridine & - & 1.20 \\
\hline 46.93 & 1,4-Bis (trimethylsilyl) benzene & - & 1.50 \\
\hline 47.37 & $\begin{array}{l}\text { 5-Bromo-4-oxo-4,5,6,7- } \\
\text { tetrahydrobenzofurazan }\end{array}$ & 28.22 & - \\
\hline & Total & 82.39 & 70.61 \\
\hline
\end{tabular}

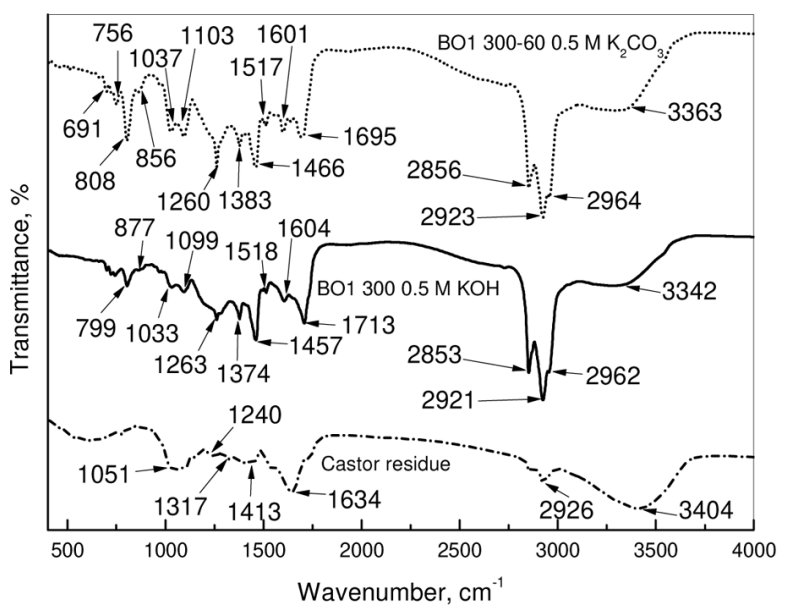

Figure 1: FT-IR analysis of castor residue and $\mathrm{BO} 1$ obtained after catalytic HTL of castor residue 


\subsubsection{Proton NMR analysis of BO1}

Figure 2 shows the ${ }^{1} \mathrm{HNMR}$ analysis of $\mathrm{BO} 1$ obtained at catalytic $\mathrm{HTL}$ of castor residue at $300{ }^{\circ} \mathrm{C}$.Proton NMR provides information of types of proton present in the compound by divulging the basic structure of the complex organic species present in BO (Dhyani et al., 2017). The spectra 0.5-1.5 ppm represents the protons on aliphatic carbon atoms at least two bonds away from $\mathrm{C}=\mathrm{C}$ or heteroatom (Singh et al., 2015b). It was observed that more aliphatic protons for the case of $\mathrm{KOH}(68.73 \%)$ as compared to $\mathrm{K}_{2} \mathrm{CO}_{3}$. The next region 1.5-3.0 ppm corresponds to protons on aliphatic carbon atoms may be bonded to a $\mathrm{C}=\mathrm{C}$ double bond or heteroatom. The protons in this region were less in $\mathrm{KOH}$ as compared to $\mathrm{K}_{2} \mathrm{CO}_{3}(28.01 \%)$. In the next zone, 3.0-4.7 ppm more protons were observed in the case of $\mathrm{K}_{2} \mathrm{CO}_{3}(8.01 \%)$, represents the protons on carbon atom next to an aliphatic ether or alcohol or a methylene group that joins two aromatic rings. The region between 4.5-6.0 ppm depicts the presence of aromatic ether protons, i.e., lignin derived phenols. The percentage of protons in this region is almost similar for both $\mathrm{KOH}$ and $\mathrm{K}_{2} \mathrm{CO}_{3}$ catalysts. The region of spectrum 6.0-8.5 ppm corresponds to aromatics, and more was observed in the case of $\mathrm{K}_{2} \mathrm{CO}_{3}(5.45 \%)$.

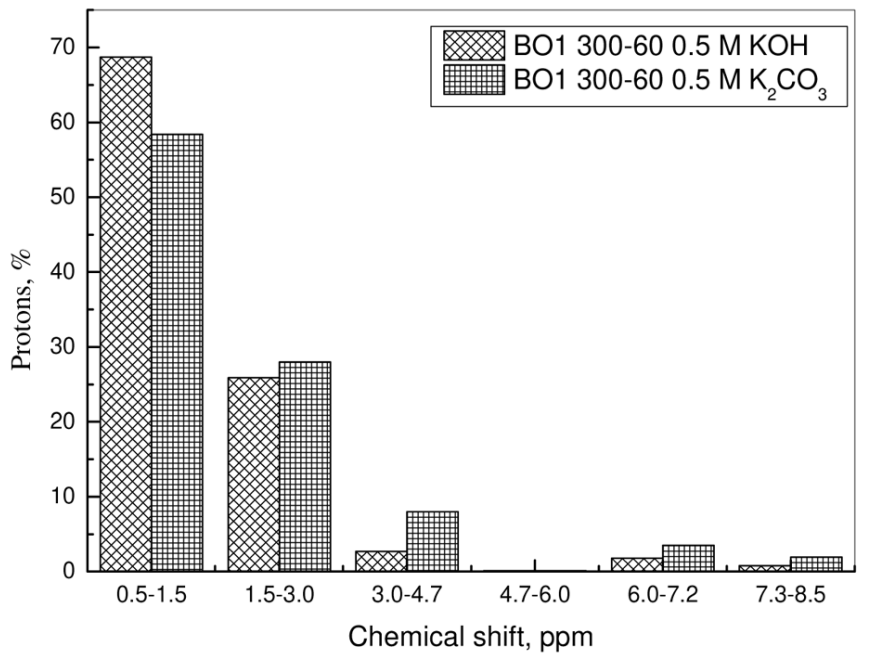

Figure 2: ${ }^{1} \mathrm{H}$ NMR analysis of BO1 obtained after catalytic HTL of castor residue

\subsubsection{Elemental analysis of $B O 1$}

Table 3 represents the elemental analysis of bio-oil 1 obtained for both HTL of castor residue using $\mathrm{KOH}$ and $\mathrm{K}_{2} \mathrm{CO}_{3}$ catalyst. $\mathrm{BO} 1$ have carbon content of $62.20 \mathrm{wt} . \%$ and $62.80 \mathrm{wt} . \%$ for $\mathrm{KOH}$ and $\mathrm{K}_{2} \mathrm{CO}_{3}$ respectively. The oxygen content of bio-oill is less in the case of $\mathrm{K}_{2} \mathrm{CO}_{3}$ as compared to $\mathrm{KOH}$. Reactions such as dehydrogenation $\left(-\mathrm{H}_{2}\right)^{3}$, decarbonylation (-CO) and decarboxylation (-COO) were involved in

\begin{tabular}{l|c|c}
\hline Elements & $\begin{array}{c}\text { BO1 300-60 } \\
0.5 \mathrm{M} \mathrm{KOH}\end{array}$ & $\begin{array}{c}\mathrm{BO} 1300-60 \\
0.5 \mathrm{M} \mathrm{K}_{2} \mathrm{CO}_{3}\end{array}$ \\
\hline Carbon, wt.\% & 62.27 & 62.80 \\
Hydrogen, wt.\% & 10.92 & 11.73 \\
Nitrogen, wt.\% & 2.22 & 2.62 \\
Oxygen, wt.\% & 24.59 & 22.85 \\
HHV, MJ/kg & 32.27 & 33.91 \\
\hline
\end{tabular}

the liquefaction process helps to reduce the oxygen content of BO1. The heating value of $\mathrm{BO} 1$ for $\mathrm{KOH}$ and $\mathrm{K}_{2} \mathrm{CO}_{3}$ are 32.27 and $33.91 \mathrm{MJ} / \mathrm{kg}$ respectively. The reduction in wt.\% of nitrogen in bio-oill was observed as compared to castor residue. Further denitrogenation and deoxygenation will be required to make this bio-oils more effective so that it can be used for transportation purposes too.

\subsubsection{Bio-char analysis}

\subsubsection{Elemental analysis of Bio-char}

The elemental analysis of bio-char obtained after catalytic HTL of castor residue at $300{ }^{\circ} \mathrm{C}$ at $60 \mathrm{~min}$ was done. The carbon, hydrogen, nitrogen, and oxygen content of bio-char obtained using $\mathrm{KOH}$ were $59.92,6.35,1.02$ and $32.71 \mathrm{wt} \% \%$ respectively. The elements present in bio-char obtained using $\mathrm{K}_{2} \mathrm{CO}_{3}$ were 59.97 wt.\% of C, 6.81 wt.\% of $\mathrm{H}$, 1.61 wt. $\%$ of $\mathrm{N}$ and 31.60 wt. $\%$ of O. The HHV of bio-char calculated using Dulong's formula were 23.50 and $24.37 \mathrm{MJ} / \mathrm{kg}$ for $\mathrm{KOH}$ and $\mathrm{K}_{2} \mathrm{CO}_{3}$ respectively. It was observed that the nitrogen content of bio-char is less as compared to castor residue.

\subsubsection{XRD analysis of Bio-char}

The XRD patterns of feedstock and bio-char were shown in Figure 3. The change in cellulose crystalline structures was observed by interrupting hydrogen bonding of cellulose chains (Mosier et al., 2005). The X-ray diffraction pattern of raw material showed two distinct peaks at $2 \theta=15^{\circ}$ and $22^{\circ}$ of cellulose. After catalytic HTL of castor residue, the shift of peaks $\left(2 \theta=29^{\circ}\right)$ towards its higher value was observed and showed the formation of hydrochar from cellulose and lignin present in lignocellulosic biomass. The change in peak intensity of bio-char for $\mathrm{K}_{2} \mathrm{CO}_{3}$ and $\mathrm{KOH}$ was may be due to the difference in component decomposition temperature, i.e., for cellulose starts at $200-250^{\circ} \mathrm{C}$ (Sakaki et al., 1996).

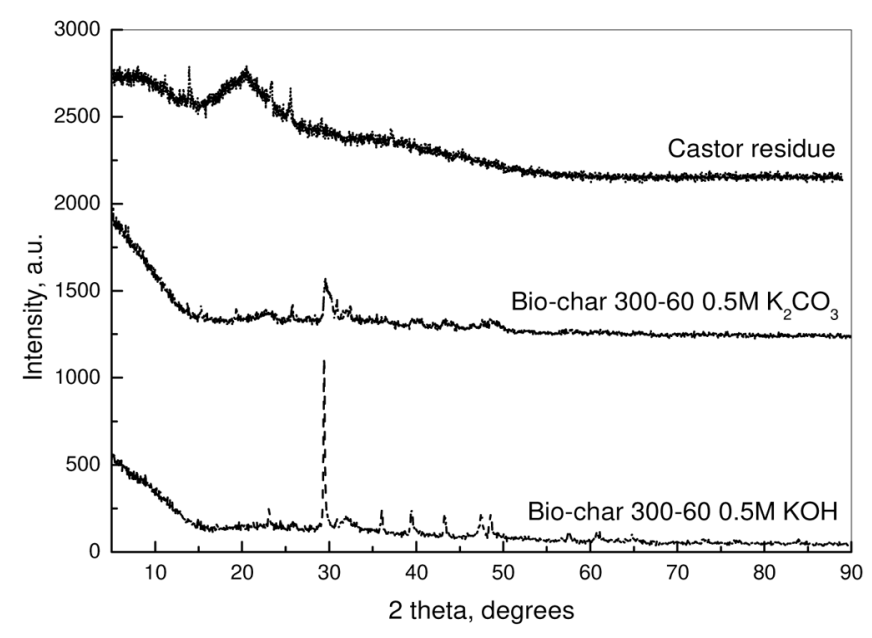

Figure 3: XRD patterns of Bio-char obtained after catalytic HTL of castor residue

\subsubsection{SEM analysis of Bio-char}

Change in the structure was observed in the micrographs of SEM as shown in Figure 4. The castor residue \{Figure 4 (a)\} as feedstock is a lumpy solid, dense matrix having strongly bounded stripes. The bio-char \{Figure $4(\mathrm{~b}-\mathrm{c})$ \} obtained using catalytic HTL $(0.5 \mathrm{M} \mathrm{KOH}$ and $0.5 \mathrm{M}$ $\mathrm{K}_{2} \mathrm{CO}_{3}$ ) shows the formation of agglomerates appeared on the surface may be due to cross-linking caused by dehydration between molecules of cellulose and hemicellulose(Sun and Li, 2004).
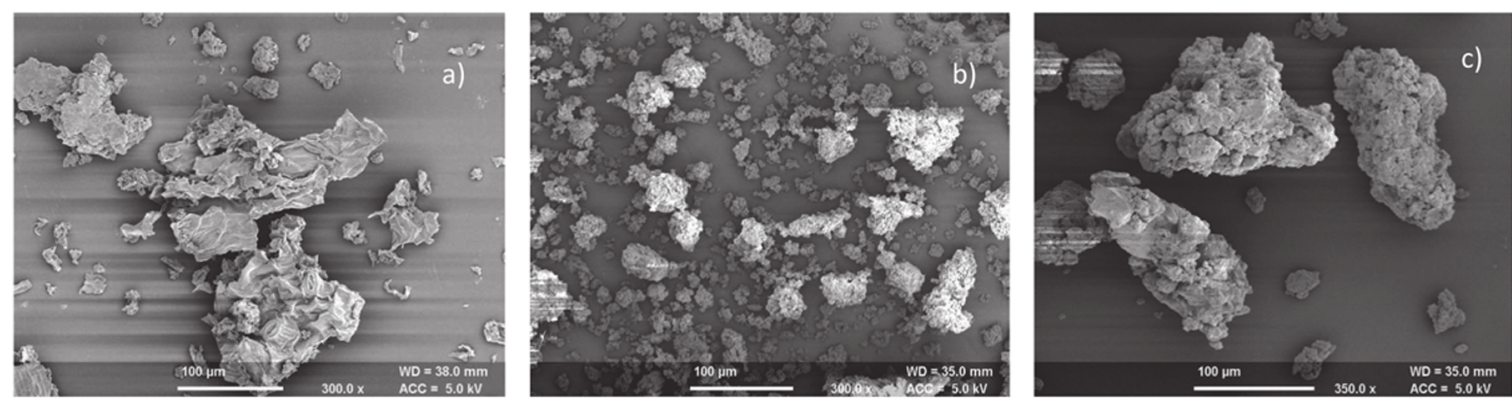

Figure 4: SEM micrographs of Bio-char obtained after catalytic HTL of castor residue 


\section{Conclusions}

Catalytic hydrothermal liquefaction of castor residue was performed in the presence of $0.5 \mathrm{M} \mathrm{KOH}$ and $\mathrm{K}_{2} \mathrm{CO}_{3}$. The maximum total bio-oil yield, ca. $21.2 \mathrm{wt} . \%$ was obtained for $0.5 \mathrm{M} \mathrm{K}_{2} \mathrm{CO}_{3}$ as compared to $0.5 \mathrm{M}$ $\mathrm{KOH}$. It was observed that the use of alkali catalyst $\left(0.5 \mathrm{M} \mathrm{K}_{2} \mathrm{CO}_{3}\right)$ enhances the total bio-oil yield.The formation of phenolic compounds was confirmed by GCMS, FT-IR, and NMR and made it promising material to be used as a phenol substitute in bio-phenolic resins. The $\mathrm{HHV}$ of $\mathrm{BO} 1$ for $\mathrm{KOH}$ and $\mathrm{K}_{2} \mathrm{CO}_{3}$ were 32.27 and $33.91 \mathrm{MJ} / \mathrm{kg}$ respectively while for bio-char it was 23.50 and $24.37 \mathrm{MJ} / \mathrm{kg}$ for $\mathrm{KOH}$ and $\mathrm{K}_{2} \mathrm{CO}_{3}$ respectively. The HHV of bio-char was more as compared to feedstock which makes it promising feedstock to be used as solid fuel in boilers, for the production of carbon nanotubes and activated carbon as well.

\section{Acknowledgments}

The authors gratefully acknowledge the Director, CSIR-Indian Institute of Petroleum (IIP) and Director, National Institute of Technology (NIT), Jalandhar for constant support and encouragement. RK would like to thank the CSIR-IIP Analytical Sciences Division (ASD) at CSIR-Indian Institute of Petroleum (IIP) for providing analytical support. RK would like to acknowledge the Elemental analysis group of IITB and testing facilities offered by SAIF and CIL labs at PU, Chandigarh. RK acknowledges MHRD, Govt of India for rendering fellowship and NIT Jalandhar for their financial support for carrying out this work.

\section{References}

Aldobouni, I.A., Fadhil, A.B., Saied, I.K., 2015. Conversion of de-oiled castor seed cake into bio-oil and carbon adsorbents. Energy Sources, Part A Recover. Util. Environ. Eff. 37, 2617-2624.

Aysu, T., 2014. Catalytic effects of ferric chloride and sodium hydroxide on supercritical liquefaction of thistle (Cirsium yildizianum). J. Supercrit. Fluids 95, 298-317. doi:10.1016/j.supflu.2014.09.024

Bateni, H., Karimi, K., 2016. Biodiesel production from castor plant integrating ethanol production via a biorefinery approach. Chem. Eng. Res. Des. 107, 4-12. doi:10.1016/j.cherd.2015.08.014

Berman, P., Nizri, S., Wiesman, Z., 2011. Castor oil biodiesel and its blends as alternative fuel. Biomass and Bioenergy 35, 2861-2866. doi:10.1016/j.biombioe.2011.03.024

Bhaskar, T., Sera, A., Muto, A., Sakata, Y., 2008. Hydrothermal upgrading of wood biomass: influence of the addition of K2CO3 and cellulose/lignin ratio. Fuel 87, 22362242 .

BP Statisitical Review of World Energy. Online Available at:https://www.bp.com > dam > global > corporate > pdfs > energy-economics. Accessed on 23rd August 2019.

Canoira, L., García Galeán, J., Alcántara, R., Lapuerta, M., García-Contreras, R., 2010. Fatty acid methyl esters (FAMEs) from castor oil: Production process assessment and synergistic effects in its properties. Renew. Energy 35, 208-217. doi:10.1016/ j.renene.2009.05.006

Comprehensive Castor Oil Report [WWW document] d.g. URL http://

www.castoroil.in/reference/report/report.html.Accessed on 25 July 2017.

Dhyani, V., Awasthi, A., Kumar, J., Bhaskar, T., 2017. Pyrolysis of Sorghum straw: Effect of temperature and reaction environment on the product behavior. J. Energy Environ. Sustain. 4, 64-69.
Guo, S., Wu, L., Wang, C., Li, J., Yang, Z., 2008. Direct conversion of sunflower shells to alkanes and aromatic compounds. Energy \& Fuels 22, 3517-3522.

Karag??z, S., Bhaskar, T., Muto, A., Sakata, Y., Oshiki, T., Kishimoto, T., 2005. Lowtemperature catalytic hydrothermal treatment of wood biomass: Analysis of liquid products. Chem. Eng. J. 108, 127-137. doi:10.1016/j.cej.2005.01.007

Kaur, R., Gera, P., Jha, M.K., 2015. Study on Effects of Different Operating Parameters on the Pyrolysis of Biomass: A Review. J. Biofuels Bioenergy 1, 135-147.

Kaur, R., Gera, P., Jha, M.K., Bhaskar, T., 2019a. Thermochemical Route for Biohydrogen Production, Biohydrogen. doi:10.1016/b978-0-444-64203-5.00008-3

Kaur, R., Gera, P., Jha, M.K., Bhaskar, T., 2019b. Reaction parameters effect on hydrotherma liquefaction of castor (Ricinus Communis)residue for energy and valuable hydrocarbons recovery. Renew. Energy 141, 1026-1041. doi:10.1016/ j.renene.2019.04.064

Kaur, R., Gera, P., Jha, M.K., Bhaskar, T., 2018. Pyrolysis kinetics and thermodynamic parameters of castor (Ricinus communis) residue using thermogravimetric analysis. Bioresour. Technol. 250, 422-428. doi:10.1016/j.biortech.2017.11.077

Liu, Z., Zhang, F.S., 2008. Effects of various solvents on the liquefaction of biomass to produce fuels and chemical feedstocks. Energy Convers. Manag. 49, 3498-3504. doi:10.1016/j.enconman.2008.08.009

Mosier, N., Wyman, C., Dale, B., Elander, R., Lee, Y.Y., Holtzapple, M., Ladisch, M., 2005 Features of promising technologies for pretreatment of lignocellulosic biomass. Bioresour. Technol. 96, 673-686. doi:10.1016/j.biortech.2004.06.025

Panwar, N.L., Shrirame, H.Y., Bamniya, B.R., 2010. CO 2 mitigation potential from biodiesel of castor seed oil in Indian context. Clean Technol. Environ. Policy 12, 579-582.

Peterson, A.A., Vogel, F., Lachance, R.P., Fröling, M., Antal, Jr., M.J., Tester, J.W., 2008 Thermochemical biofuel production in hydrothermal media: A review of sub- and supercritical water technologies. Energy Environ. Sci. 1, 32. doi:10.1039/ b8 $10100 \mathrm{k}$

Pradhan, S., Madankar, C.S., Mohanty, P., Naik, S.N., 2012. Optimization of reactive extraction of castor seed to produce biodiesel using response surface methodology. Fuel 97, 848-855. doi:10.1016/j.fuel.2012.02.052

Sakaki, T., Shibata, M., Miki, T., Hirosue, H., Hayashi, N., 1996. Reaction model of cellulose decomposition in near-critical water and fermentation of products. Bioresour. Technol. 58, 197-202.

Santos, N.A. V, Magriotis, Z.M., Saczk, A.A., Fa ssio, G.T.A., Vieira, S.S., 2015. Kinetic study of pyrolysis of castor beans (Ricinus communis L.) presscake: an alternative use for solid waste arising from the biodiesel production. Energy \& Fuels 29, 2351-2357.

Singh, R., Balagurumurthy, B., Prakash, A., Bhaskar, T., 2015a. Catalytic hydrothermal liquefaction of water hyacinth. Bioresour. Technol. 178, 157-165. doi:10.1016/ j.biortech.2014.08.119

Singh, R., Bhaskar, T., Dora, S., Balagurumurthy, B., 2013. Catalytic hydrothermal upgradation of wheat husk. Bioresour. Technol. 149, 446-451. doi:10.1016/ j.biortech.2013.09.092

Singh, R., Chaudhary, K., Biswas, B., Balagurumurthy, B., Bhaskar, T., 2015b. Hydrothermal liquefaction of rice straw: Effect of reaction environment. J. Supercrit. Fluids 104, 70-75. doi:10.1016/j.supflu.2015.05.027

Sun, X., Li, Y., 2004. Colloidal Carbon Spheres and Their Core/Shell Structures with Noble-Metal Nanoparticles. Angew. Chemie - Int. Ed. 43, 597-601. doi:10.1002/ anie. 200352386

Thiagarajan, J., 2016. Thermogravimetric and Decomposition analysis of Jatropha, Castor and Pongamia Deoiled seed cakes.Int. J. Innov. Eng. Technol.7, 417-425.

Xiu, S., Shahbazi, A., 2012. Bio-oil production and upgrading research: A review. Renew. Sustain. Energy Rev. 16, 4406-4414. doi:10.1016/j.rser.2012.04.028 